\title{
A 'CHIEF ERROR' OF PROTESTANT SOTERIOLOGY: SIN IN THE JUSTIFIED AND EARLY MODERN CATHOLIC THEOLOGY
}

\author{
MATTHEW T. GAETANO*
}

Hillsdale College

\begin{abstract}
Catholic theologians after Trent saw the Protestant teaching about the remnants of original sin in the justified as one of the 'chief' errors of Protestant soteriology. Martin Luther, John Calvin, Martin Chemnitz, and many Protestant theologians believed that a view of concupiscence as sinful, strictly speaking, did away with any reliance on good works. This conviction also clarified the Christian's dependence on the imputed righteousness of Christ. Catholic theologians condemned this position as detracting from the work of Christ who takes away the sins of the world. The rejection of this teaching-and the affirmation of Trent's statement that original sin is taken away and that the justified at baptism is without stain or 'immaculate' before God-is essential for understanding Catholic opposition to Protestant soteriology. Two Spanish Dominican Thomists, Domingo de Soto and Bartolomé de Medina, rejected the Protestant teaching on imputation in part because of its connection with the view on the remnants of original sin in the justified. Adrian and Peter van Walenburch, brothers who served as auxiliary bishops of Cologne in the second half of the seventeenth century, argued that the Protestants of their time now agreed with the Catholic Church on a number of soteriological points. They also drew upon some of their post-Tridentine predecessors to offer a Catholic account of the imputation of Christ's righteousness. Nonetheless, the issue of sin in the justified remained a point of serious controversy.
\end{abstract}

KEYWORDS: original sin, justification, imputation, the Council of Trent, Domingo de Soto

In 1520, Pope Leo X's Exsurge Domine condemned Martin Luther for the following assertion: 'To deny that sin remains in a child after baptism is to trample upon both Paul and Christ alike' (Denzinger 2012: no. 1452, modified translation; cf. Luther 1957: 317). The pope and his theologians saw Luther's teaching about the perdurance of original sin in the baptized as intolerablea view of the Protestant reformer associated with the formula that the justified person is simul iustus et peccator (at the same time righteous and a sinner). Decades later, the Council of Trent's fifth session anathematized anyone who denied that 'the guilt of original sin is remitted by the grace of our Lord Jesus Christ given in baptism' (Denzinger 2012: no. 1515). The Council Fathers 
taught that 'all that is sin in the true and proper sense' is 'taken away' and condemned those who said that sin is 'only brushed over or not imputed'. The question of the non-imputation of original sin that remains in the baptized was thus a central point of contention in the unfolding of the Protestant Reformation and remains an obstacle to ecumenical progress even today (Joint Declaration 2000: 20-22, 34-35; Malloy 2005: 275-80, 343-44; Lane 2006: 167-76; Anderson, Murphy, Burgess 1985: 51-52; Hampson 2001; O'Gara 2006: 34-41; Root 2006; Hoskins and Fleischacker 2017: 15-16). While Protestants saw a number of Catholic soteriological teachings as undermining the all-sufficiency of Christ's work on the cross, Catholic theologians likewise insisted that this Protestant view of the remnants of original sin in the baptized undermined Christ's work. Is Jesus not the Lamb of God who takes away the sins of the world? The insistence on the removal of original sin in the baptized led Trent to say that the baptized 'are made innocent, immaculate, pure, harmless, and sons beloved to God, heirs of God and fellow heirs with Christ' (Denzinger 2012: no. 1515, modified translation). This debate about the 'immaculate' character of the baptized had a fundamental role in the controversies of post-Reformation theology. After decades of polemical exchanges and refinements in Protestant and Catholic discussions of justification, some Catholics—-such as the Walenburch brothers who feature prominently below-saw the possibility of greater agreement between Catholics and Protestants on issues such as the central role of faith in justification, the assurance of salvation, the forensic character of justification, and even the imputation of Christ's righteousness. Nonetheless, the way of understanding the sinfulness of Christians remained a major point of contention.

These post-Reformation controversies about the remnants of original sin in the baptized must be examined in the context of the shared anti-Pelagianism of Protestant and Catholic theologians during this period. Although early modern theologians frequently charged their opponents with the Pelagian heresy (or Semipelagianism) (Backus and Goudriaan 2014; Ballor, Gaetano, Sytsma 2019b), both sides opposed the view that one's works apart from grace merit salvation. Trent's sixth session on justification condemned those who said that one may be justified before God 'by his own works' without 'divine grace through Jesus Christ' (Denzinger 2012: no. 1551). Trent required one to affirm the 'prevenient inspiration of the Holy Spirit' for acts of faith, hope, and love, and rejected the notion that grace merely made meritorious works easier to perform (Denzinger 2012: nos. 1552-53). Decades after the Council, another major soteriological debate drew the attention of the papacy. Luis de Molina's Concordia, which sought to show the harmony of free choice with grace, foreknowledge, providence, and predestination, was examined in Rome during the Congregatio de auxiliis (1597-1607) to determine whether Molina made the auxilium (aid or help) of God too dependent on human 
choice. Though neither Molina's works nor those of his Dominican Thomist opponents were ultimately censured by the papacy, both Jesuits and Dominicans held up Augustine's anti-Pelagian doctrine of grace as a standard throughout the controversy (Lemos 1702: 1-180; Serry 1709: 315; Matava 2016: 2-3, 19). Moreover, despite the condemnation of positions such as Baianism and Jansenism that claimed the mantle of Augustine, the popes and the opponents of these positions continued to uphold the 'unshaken' teaching of Augustine on grace throughout this period (Bryas 1674; Gonet 1875: 537-84; De Franceschi 2018: 232-34; cf. Kolakowski 1995: 23, 29, for a view of the Church as having condemned Augustine along with Jansenism). It is thus deeply misleading when scholars suggest that the Reformation was a struggle in the mind of Augustine-with Protestants adopting his teaching on grace and Catholics claiming his teaching on the church (MacCulloch 2003: 108, 179; cf. Rorem 2001, for an insightful challenge to this position).

Within this broadly Augustinian framework, controversy still raged between Catholics and Protestants about whether their opponents' teachings about salvation were consistent with Scripture and the Church Fathers. Both Catholics and Protestants saw the issue of the remnants of original sin in the baptized as fundamental to these soteriological controversies. In Luther's reply to Leo X's condemnation of the second article about sin remaining in the baptized, the Wittenberg reformer affirmed the teaching being condemned by the pope. He quoted a number of passages of Scripture that point to the struggle of the spirit with the flesh and its lusts (Genesis 3:15; Romans 6:12, 7:7, 7:18; Galatians 5:17, 5:24; 1 Peter 2:11), and he said, 'From all this it is evident that sin remains in the baptized and the saints as long as they are flesh and blood and live on earth and that the condemnation of this article in the bull is most un-Christian' (1958: 19-20). Luther then quoted Paul's words in Romans 7:23 about 'the law of sin which dwells in my members' and asked, 'How is it then possible to deny that sin remains in a holy baptized man? If it is not sin which is at war with the good spirit and the law of God, then I would like to be told what sin is' (1958: 20). Theologians on both sides acknowledged that rebellious concupiscence is a consequence of Adam's sin and remains after baptism as the fomes peccati or fuel of sin. Rebellious concupiscence was a defect and a source of temptation.

Luther, however, saw this position as profoundly insufficient and said that he was 'willing to let sin be sin' (1958: 27; cf. Batka 2014; Pereira 2013: 328). While God 'does not hold against us whatever sin is still to be driven out, because of the beginning that we have made in godliness and because of our steady battle against sin which we continue to expel', the concupiscence that remains after baptism is sin: '[God] chooses not to charge this sin against us, though, until we become perfectly pure, he might justly do so' (1958: 28). This remaining impurity requires a shield in order to withstand divine 
scrutiny, which led to a statement of the imputation of Christ's righteousness: 'For this reason, God has given us a bishop, namely Christ, who is without sin and who is to be our representative until we too become entirely pure like him. Meanwhile, the righteousness of Christ must be our cover. His perfect godliness must be our shield and defense. For his sake, the sin that remains in those who believe in him, may not be charged against them, as St. Paul so masterfully describes it in Rom. 3[:24-26]' (1958: 28; cf. Clark 2006: 290-94; Maas 2019: 673-76). Christ's perfect righteousness covers the impurity and sin that remains in the flesh of the baptized, even in the midst of the most fervent struggles of the saints against sin.

Luther believed his teaching about the perdurance of sin in the baptized resonated not only with the experience of the saints but also had an essential role in maintaining the continual dependence of the baptized upon Christ. 'How often', Luther asked, 'does St. Jerome lament that evil desire rages in his flesh, not only after baptism, but even when he had fasted, watched and labored unto weariness and was most saintly?' (1958: 22). The 'lives and confessions of these and all other saints' corroborated Paul's teaching that a 'law of sin' dwells in the members of the baptized; 'no one can deny', Luther said, 'that sin is still present in all the baptized and holy men on earth, and that they must fight against it' (1958: 22; cf. Luther 1961: 124-39). Without an acknowledgement of the continued presence of sin, Luther thought that Christians failed to depend on Christ's righteousness as a shield. When wrongheaded theologians 'hide our sin from us and make it out to be merely a weakness', they 'lull us into a false security, make us lazy and sullen, take Christ from us' (1958: 29). Luther's teaching of the sinfulness of the baptized Christian-even before any assent of the will to the concupiscence or 'flesh' pointed to the experience of the Christian as being anything but pure and immaculate. Luther saw this teaching on the true sinfulness of the concupiscence that remains after baptism as a way of making Christians depend more upon Christ and of looking to his perfect righteousness as a shield. For him, the view that that original sin is entirely taken away led Christians into 'horrible presumption' (Luther 1958: 29).

Later theologians in the Lutheran tradition agreed about the importance of this controversy. Martin Chemnitz, a key contributor to the major Lutheran confessional document, the Formula of Concord, and sometimes called the 'second Martin', dedicated an entire section of his Examination of the Council of Trent to the debate about the remnants of original sin after baptism (1578: 103-16; cf. Chemnitz 1615: 245-52; MacDonald 2018). Chemnitz said that this issue is one of the chief controversies, and it is being argued with great contention by our opponents. For on this depends the merit, perfection, righteousness, and supererogation of good works before the judgment of God' (1971: 335). According to Chemnitz, Roman Catholics opposed 
the Protestant teaching on sin in the baptized as a way of defending their view of good works. But the shape of the controversy was not entirely clear; Chemnitz suggested that the bishops and theologians at Trent 'mix in slanders' when they indicated that Lutherans 'taught that original sin is and remains in the regenerate after Baptism in clearly the same manner and in altogether the same way as it is before Baptism in the unregenerate and that it is the same sin, whether the regenerate resists it or whether he obeys the desires of concupiscence' (1971: 335). Chemnitz thus sought to clarify that the remnants of original sin after baptism were not the same as original sin in the 'unregenerate' and that resisting concupiscence is obviously better than surrendering to it (cf. Bellarmine 1870: 553, who asserted that Chemnitz defended this Protestant position more 'cautiously' than his predecessors). He also knew that Roman Catholic defenders of Trent accused the Lutherans of 'blaspheming the grace of God, the merit of Christ, Baptism and faith, as if they were so weak that they could not suddenly in one moment remove the entire original sin in the baptized and root it out from human nature' (1971: 335). Although Chemnitz accused his Roman Catholic opponents of slandering the Lutherans, he grasped that part of what was at stake in the debate was the power of Christ's merit and the sacrament of baptism.

Chemnitz argued that this is not merely 'a strife about words' (1971: 342). Both sides affirmed that concupiscence remains in the baptized, but Trent nonetheless taught that that 'the regenerate are spotless, pure, and blameless' (Chemnitz 1971: 343). For the Tridentine bishops and theologians, Paul's words in Romans 8:1 that 'there is no condemnation to them that are in Christ Jesus' meant that the concupiscence which remains after baptism is not condemned because it is 'by its nature' not worthy of damnation. Chemnitz believed that the Lutherans stood with Paul in Romans 7 who bewailed 'the evil of concupiscence that dwells in him' and that this concupiscence is not condemned or imputed 'because of Christ'. This contention was thus not just about an 'idle' controversy about terminology—-that is, about whether to call concupiscences sin or not-but 'about the most serious matters'. For Chemnitz, the 'papists' insisted on this point to support their teachings about the capacity of the regenerate to fulfill the law and about the merit of good works. By contrast, Chemnitz believed that the Lutheran teaching on the true sinfulness of concupiscence helped Christians to avoid 'Pharisaical pride about a pure and spotless heart'. Christians would not depend on any of their works because 'the works of the regenerate are in this life neither perfect nor clean in every part' on account of 'the indwelling sin' (1971: 344). This view about the remnants of original sin in the baptized gave the glory due 'to the Son of God, the Mediator' who does not cease 'to be our Reconciler, our Righteousness', who 'as the true Mercy Seat covers and overshadows with His obedience the body of death and the flesh in which no good thing dwells, in 
order that the indwelling evil may for His sake not be imputed to damnation' (1971: 343).

It is crucial to recognize that, for Chemnitz, the doctrine of justificationthe 'chief topic in the Christian doctrine' (1971: 461)—'depends' on a proper understanding of original sin and its remnants in the baptized (1615: 25152). The connection is essential because, for Chemnitz, Christians more fully depend on Christ's work when they recognize that they 'please God and have been accepted to eternal life, not because of their own purity, as though no evil adhered to it any longer, but with a humble confession they acknowledge and lament that in their flesh no good thing dwells' (1971: 344). The teaching on the remnants of original sin leads to thanksgiving to God that the sins of believers are not imputed and that they 'are blessed because their sins are covered' (cf. Romans 4:7). Instead of thinking of the remission of sins as happening 'only once in Baptism', Christians 'are daily admonished that they are to strive to remain in Christ, in order that for His sake this evil which dwells in the flesh may not be imputed, which, if we were without Christ, could condemn us' (1971: 344). As an architect of the Formula of Concord, Chemnitz's arguments shed light on the following words from chapter 3 on the Righteousness of Faith from the Solid Declaration: 'But when we teach that through the operation of the Holy Ghost we are born anew and justified, the sense is not that after regeneration no unrighteousness clings any more to the justified and regenerate in their being and life, but that Christ covers all their sins which nevertheless in this life still inhere in nature with His complete obedience'. Despite the fact that they are declared righteous 'by faith and for the sake of Christ's obedience', because of 'their corrupt nature, they still are and remain sinners to the grave' (Triglot Concordia 1921: 923).

The Reformed tradition embraced a similarly strong view of the remnants of original sin in the baptized. Although the Reformed tradition arguably began with Ulrich Zwingli, who held, at the very least, an ambiguous view of original sin even in the unbaptized as merely a 'sickness' and as not 'sin in the strict sense of the term', John Calvin, Peter Martyr Vermigli, Martin Bucer, and others affirmed a teaching very similar to that of Luther, Chemnitz, and the Formula of Concord (Pelikan 1984: 225-26; cf. Castaldo 2019: 832, for a clear account of Vermigli's view of sin in the justified). John Calvin's Antidote to the Council of Trent addressed the fifth session of Trent's statement about sin in the baptized directly. For Calvin, 'the whole guilt of sin is taken away in baptism, so that the remains of sin still existing are not imputed' (1975: 153; 1547:124). Like Chemnitz, Calvin made clear that all sin is forgiven at the moment of justification. Nonetheless, there was a need for a nonimputation of the remnants (reliquiae) of original sin. Calvin pointed out that the 'twofold grace (duplex gratia) in baptism' involves the remission of sins and regeneration (1975: 153; 1547: 124). While justification, which takes away all 
of our guilt, is complete, renewal and sanctification is not completed in this life (cf. Billings 2007: 106- 108; Helm 2010: 211-16; Stamps 2019: 522-25). Because of the inchoate or incomplete nature of sanctification, Calvin said that 'sin truly remains in us, and is not instantly in one day extinguished by baptism' though 'as the guilt is effaced it is null in regard to imputation' (1975: 153). The Council of Trent said that 'there is nothing in the regenerate which God hates'. Calvin replied that he could not entirely grant this teaching because it might imply that 'there is nothing deserving of hatred', which is untrue because God 'pardons what he might justly hate'. There is still something worthy of hatred and even damnable in the baptized (Raith 2014: 17677). Calvin argued that believers are not 'pure and free from all sin' but only freed from guilt in such a way that, though 'groaning under the burden of sin', they are consoled because the justified are "clothed with the innocence of Christ'. The connection between the remnants of original sin in the baptized and the imputation of Christ's righteousness is clear.

In contrast with the 'horned fathers' of Trent, who said that the baptized are 'pure', Calvin wanted to acknowledge that Christians in this life are not pure or immaculate-that they are still 'putting off the old man' (1975: 153$54)$. Both sides agreed that concupiscence remains in the baptized, but Calvin said that concupiscence 'of its own nature ... is sin, although it is not imputed' (1975: 155). Indeed, because of the old man, baptized Christians do not love God with their whole heart, mind, and strength, and Calvin argued that 'the law ... requires perfect love'. Decades later, the Westminster Larger Catechism (q. 78) restated the longstanding Reformed teaching: 'The imperfection of sanctification in believers ariseth from the remnants of sin abiding in every part of them, and the perpetual lustings of the flesh against the spirit; whereby ... their best works are imperfect and defiled in the sight of God' (quoted in Kolb and Trueman 2017: 53).

The Magisterial Protestant teaching on the true sinfulness of concupiscence in the justified intended to show the mercy of God in not imputing sin that remains in them. It sought to clarify the need for the imputation of Christ's righteousness as a shield or defense and to destroy any dependence on works because even those works done by the justified are not free from the impurity of the flesh and do not perfectly fulfill the law of love. The forensic character of justification is not rooted exclusively in a philological observation about the proper understanding of the Greek word dikaioō; for these Protestant theologians, one is declared just and is not made just because sin, properly speaking, still clings to the believer. This important controversy between Protestants and Catholics was not primarily about how one finds a gracious God or even how one is justified but about the character of the Christian life. 
Catholic theologians saw this Protestant teaching about the remnants of original sin after baptism as a fundamental error. As noted above, Leo X and the Council of Trent both targeted this view for condemnation. Domingo de Soto, who taught at the University of Salamanca and served as a theological advisor to Trent during its sessions on original sin and justification, saw the Protestant teaching on original sin in the baptized as an error which is the source of many other errors. In his work On Nature and Grace, an articulation of the Tridentine teaching on original sin and justification in light of its biblical, Augustinian, and Thomistic sources, Soto argued that no one before Luther in Church history had ever seen original sin as so deeply 'thrust' into the soul that even God's grace does not completely take it away (1549: 36v, 33v; cf. Wiley 95-96, who associates Luther with a major theologian like Peter Lombard, though it is important to note that Counter-Reformation theologians-Bellarmine 1873a: 440_argued that there were key differences between them). Fully aware that Protestants charged Roman Catholic theology with detracting from the perfection of Christ's work on the cross, Soto argued that this teaching not only took away from the sacraments of Christ but alsoechoing the words of Luther condemned in Exsurge Domine - 'tramples Christ himself' (1549: 39r). He quoted Scripture about being 'cleansed from all your iniquities' (Ezekiel 36:25, 31) and about God 'blott[ing] out your iniquities as a cloud' (Isaiah 44:22). A key passage for Soto was the proclamation of John the Baptist: 'Behold the Lamb of God ... who takes away the sins of the world' (John 1:29) (39rv). Soto realized that this disagreement about whether original sin is entirely taken away led to the controversies about whether righteousness is imputed or infused, whether the good works of Christians are sinful or meritorious, and so on (1549: 36v-37r, 173v-175r, 178v, 224rv). Indeed, Soto referred to the Protestant teaching on the inability to fulfill the divine law with grace as the 'sprout of that pestiferous root', and the root was the Protestant position on the sinfulness, properly speaking, of concupiscence in the baptized (1549: 199rv; cf. 1549: 211v).

Although Soto brought up the divergence in the Church Fathers about whether Romans 7 pertains to Christians, Soto acknowledged the longstanding tradition that the 'law of sin' does 'dwell in the members' of the baptized (1549: 44r; 1551: 197). But Soto argued that concupiscence detached by justification from the 'guilt (reatus) of original sin' does not 'have the ratio of sin' (46v). The struggle against concupiscence is not only free from sin but is indeed praiseworthy. Soto believed that concupiscence is not merely an effect and cause of sin but 'a wound'-'an evil of nature which fights with reason'. Nonetheless, the justified, through the exercise of the virtues shaped by the charity infused by God, 'crush, diminish, and drain' the power and strength of this evil 'day by day' until 'Christ our Wrestler' refashions 'the body of our humility' and configures it 'to the body of his brightness'. Thus, the justified 
can both be immaculate at the point of baptism because everything that is essentially sinful is taken away but still cry out for the final deliverance from the 'law of sin' and the 'body of death'-from this 'evil of nature' that is the source of daily struggle. For Soto, when Augustine said in Marriage and Concupiscence 1.25/28 that concupiscence is not imputed after baptism-a passage to which Luther referred in his reply to Leo X (1958: 28; cf. Bellarmine 1870: 553, for more detail about the Counter-Reformation controversy over Luther's supposed misquotation of this passage) - he did not mean that concupiscence was still worthy of condemnation but not condemned because of God's merciful non-imputation and the imputation of Christ's righteousness. Rather, according to Soto, Augustine thought concupiscence was not imputed inasmuch as it was not a true fault (culpa). According to Soto, Augustine taught rather frequently that concupiscence after baptism was only called sin by metonymy (1549: 45r). For Christians, concupiscence is not a true sin or the source of guilt unless the will consents. Indeed, just a few chapters before the contested passage from On Marriage and Concupiscence, in 1.23/25, Augustine taught that 'concupiscence is not a sin in those who have been reborn, unless consent is added' (Soto 1549: 45r; cf. Augustine 1998: 44: 'concupiscence itself, after all, is not now a sin in those who have been reborn, provided they do not consent to it for acts that are forbidden and the mind, remaining sovereign, does not hand over the members to it to carry out those acts').

One of Soto's successors as the primary professor of theology at Salamanca, the Dominican Bartolomé de Medina, viewed the teaching on the remnants of original sin in the justified as the greatest error of Protestantism in soteriology. In his commentary on the Prima secundae of Thomas Aquinas's Summa theologiae, Medina wrote, 'Among the many errors of the Lutherans, this is the chief one (praecipuus), that in the justification of the ungodly, when sins are remitted, those sins are not taken away, but, to those who believe in Him who justifies the ungodly, their sins are simply not imputed, while still actually remaining' (1580: 630). By contrast, for Medina, 'the truth of the Catholic faith holds that, in the justification of the ungodly (in iustificatione impii), sins are remitted in such a way that nothing of them remains damnable or culpable before God' (1580: 631). Medina set up a series of contrasts between the formulations of Scripture and Luther: Christ prayed for the Father to 'sanctify them in truth' (John 17:17), while Luther said that 'we are not truly holy (sancti) but are only reckoned as holy'; Christ taught, 'if the Son shall make you free (liberaverit), you shall be free indeed' (John 8:36), while Luther said that 'we are not truly liberated from sin'; John said that the one who 'does justice is just' (1 John 3:7), while Luther argued that it is 'not the one who does justice who is just but the one to whom sins are not imputed' (1580: 631). And the contrasts between Scripture and Luther continued until Medina concluded with the words of Isaiah that the Lord is the one who 'blots 
out your iniquities' (Isaiah 43:25), with John the Baptist's proclamation of Christ as the 'Lamb of God ... who takes away the sins of the world' (John 1:29), and with John of Patmos and Paul who said that Christ 'washed us from our sins in his own blood' (Revelation 1:5) and 'delivered us from the power of darkness' (Colossians 1:13).

Medina thought that Trent rightly condemned the 'most foolish' teaching of Protestants on sin in the justified. Does God hate the concupiscence that remains in the baptized or not? If not, Medina thought that it would not truly be sin. If God still hates it, then he has not truly forgiven or remitted it, for a sin is remitted when the offender and the offended are reconciled. For Medina, God does not hate the concupiscence in the baptized not because it is not imputed or shielded by Christ's righteousness but because it is not a sin, 'properly and truly speaking' (1580: 631). Concupiscence is sometimes called sin because it is the tinderbox or fuel (fomes) of sin and the effect of the first sin of Adam.

Besides the sinfulness of concupiscence in the justified, another Protestant argument for the sinfulness of Christians was the inability to fulfill the commandment to love God with one's whole heart. This inability partly springs from the remnants of original sin in the baptized. For Medina, though Christians do not love God as much as they will in heaven, they are not as a consequence always committing sins. Medina quoted 1 John 2:5, which teaches that 'the charity of God is perfected' in the one who 'keeps his word' (1580: 631). Thus, the one who is in a state of grace and keeps God's word loves God above all things in such a way that the commandment is satisfied.

When Scripture speaks about God covering sin (Romans 4:7), this is clearly different from the way that crimes are hidden from a human judge. When God 'does not impute sin' (cf. Romans 4:8), this means for Medina that God 'cleanses from sin and truly makes [that person] just'. Medina cited Aquinas's reply to the second objection of I-II, q. 113, a. 2, which invoked the word of David (Psalm 31[32]:2) quoted by Paul in Romans 4:7 about God not imputing sin: 'As God's love consists not only in the act of the divine will but also brings about a certain effect of grace ..., so likewise, when God does not impute sin to a man, there is brought forth a certain effect in him to whom the $\sin$ is not imputed; for it proceeds from the divine love that sin is not imputed to a man by God'. When God does not impute sin, it brings about an effect of his grace in the soul; it is not entirely extrinsic. Moreover, God does not actually forget the sins of human beings when they repent, but this image from Scripture (e.g., Isaiah 43:25, Hebrews 8:12) communicates the 'mode of handing over to oblivion by not punishing sins which we have done' (1580: 631). Medina's teacher, Soto, developed this point at greater length in his commentary on Romans 4:7-8 where he echoed Aquinas's formulation in his commentary on these important words from Romans and Psalm 31[32]:2: 
'blessed is the man whose sins are covered' and 'to whom the Lord has not imputed sin'. For Aquinas, one whose sins are covered is blessed, not because God shields a stain that remains in the baptized, but because the fact that a believer has committed a sin-'the stain of the past act of sin'-'is covered by the hand of God's mercy and is held as if not having been done' (quoted and discussed in Marshall 2012: 232; cf. Raith 2014: 69-72, 173). God does not change the past; Aquinas linked the covering of sins with the Psalmist's request for God to 'turn away your face my sins' (Marshall 2012: 233; Psalm $50[51]: 11)$. Soto spoke about 'the great mercy of the mercy of God who covers (contegentis Dei misericordia)' and 'the great efficacy of charity covering a multitude of sins and likewise of abolishing them as if they were never perpetrated' (1551: 123; for Catholic treatments of Romans 4:7-8 that drew out similar themes in the passage, cf. Nacchiante 1557: 83rv; Pereira 1603: 51116). For Medina, these images of God covering sins and concealing them on account of charity, however, do not rule out the other biblical images of God throwing them into the depths of the sea, taking them away, and cleansing them (1580: 631).

The Catholic rejection of Protestant accounts of the imputation of Christ's righteousness often related to their concern about its connection with the sin that remains in the baptized. Luther, Chemnitz, Calvin, and others made clear that the teachings of the remnants of original sin and the imputation of the righteousness of Christ were related. In Soto's On Nature and Grace, he rejected the Protestant way of speaking about God's non-imputation of remnant $\sin$, but he recognized the prima facie attraction of the idea of the imputation of Christ's righteousness. 'When heard only in a superficial way', he said, it cannot but seem plausible. Upon first hearing [that the justice through which we are formally just is the justice which is formally in Christ and which is indeed imputed to us as if we had done the very same], one thinks of nothing except that our works of themselves are not the cause and merit of our justification' (1549: 176v-177r). And Soto said, 'nothing more orthodox and holy can be said' (1549: 177r). Indeed, Soto made clear that Christ's righteousness - and not human works-merits and is an efficient cause-with the Triune God-of true righteousness in Christians (1549: $132 \mathrm{v}-134 \mathrm{r}, 178 \mathrm{rv}, 180 \mathrm{r}, 182 \mathrm{v})$. Christ is the Head; they are the members (1549: 179v-180r). He is the vine; they are the branches (1549: 180r). Christ is the Sun and source of light; they are merely the sky illuminated by the sun's brightness (1549: 179v, 180v, 182v). Soto's concern, therefore, was not with the Protestant idea of depending on Christ's righteousness and his work on the Cross, something which he affirmed (1549: 180rv); instead, he rejected the idea, as he understood it, that the insufficiencies of the infused and inherent righteousness in the soul of the justified needed to be covered or supplemented by Christ's perfect righteousness. Soto thought that his opponents 
improperly thought of the relationship between Christ and the justified like two men before a ruler rather than as light in the sun and the sky or as cause and effect. He said, 'the entirety of our righteousness depends on Christ's' just as the illuminated sky or air depends on the sun; without the sun, 'there would be no light in the air' (1549: 180v). The light in the sky does not supplement any defects in the sun but is the effect of the sun's light (1549: 182v). This grace that becomes the form of the righteous soul is 'the effect of Christ' and renders the justified children of God and heirs of the heavenly kingdom (1549: 179v). Indeed, Soto said, 'by no means do we deny that the justice of Christ is imputed to us. Nevertheless, this is absolutely nothing other than the infusion of grace and the gifts by which we are made its partakers' (1549: 180r). Soto was willing to employ the language of imputation but associated it closely with its communication and infused grace (cf. 1549: 179r).

Soto's problem with the Protestant account of imputation went back in part to his rejection of the Protestant idea of the non-imputation of sins that still cling to the believer. This view led to the notion that the works of Christians are corrupted by sin or defiled before God: 'we deny without question that [the works of a man already infused with grace are] imperfect in the sense in which the [Lutherans] think' (1549: 179v). Indeed, the 'smallest degree of God's grace', which flows from the head to its members, establishes friendship and abolishes enmity between God and the human being. This state of friendship with God is the effect of Christ's work and is merited by Christ's work; it does not require a special imputation of Christ's righteousness to cover its perduring sinfulness.

Medina took up the question of whether 'we are justified by the external righteousness (iustitia) by which Christ is just' (1580: 631). He began his refutation of the Protestant position by once again pointing to the Protestant 'error' about the justified not being 'truly just' but only 'reckoned as just (reputantur iusti)'. For Medina, no good works are required in the Protestant framework, and certainly no works could make satisfaction for temporal punishments after the sacrament of penance because, for Protestants, those works are contaminated by sin and also because Christ's satisfaction 'is infinite and is our own' (1580: 632). Although he opposed this Protestant formulation, Medina affirmed the anti-Pelagian teaching that the righteousness by which Christians are just before God is 'not from us, nor acquired by the powers of free choice'. Indeed, if true righteousness could be acquired in this way, Medina said that Christ would have died in vain. The justice by which human beings are just before God is 'a special (eximium) gift of God poured out in our hearts' (1580: 632).

Nonetheless, this gift is not the very righteousness of Christ (or the Triune God) as that righteousness exists in him. Like Soto, Medina explained the relationship with the image of light. The sky (aer) is not bright by the very 
brightness that is in the sun but by the brightness which the sky 'receives from the sun'. And Medina quoted Augustine's On the Spirit and the Letter where the Bishop of Hippo explained Paul's words in Romans 3:21 that 'the justice of God is made manifest' as pointing not to the justice of God by which God is just but that justice with which he endows (induit) man when God justifies the ungodly. Christ's righteousness is imparted to the one with living faith according to a certain measure, which would not be true if every Christian were justified by the very righteousness which remains in Christ. In that case, every Christian's justice would be equal, but Paul taught that 'star differs from star in glory' or charity (1 Corinthians 15:41) (Medina 1580: 633). Moreover, Medina pointed out that Christians are all 'one body in Christ' (Romans 12:5), but, 'though each member participates in the same life, they do so in a different order and a different degree' (1580: 633). This account of how infused or imparted righteousness allows for diversity within the body of Christ-in a way that the imputation of Christ's perfect righteousness does not-still points back to the concern about the Protestant account of sin in the Christian life: 'Luther says that Christ brings about (efficit) that we are just through the extrinsic justice which remains in him-with us remaining in our iniquities. From this, it immediately follows that [God] reckons (reputat) just those who are not in fact just' (1580: 633).

The issue here for Medina was not only the desire to protect the good works of Christians but also the desire to defend the good judgment of God. God could not 'call evil good and good evil' (Isaiah 5:20); God is not an unjust judge who would 'justify the wicked for gifts' or bribes (Isaiah 5:23). How could the Protestant account fulfill God's promise provided by Ezekiel: 'I will give them [a new] heart, and will put a new spirit in their bowels' (Ezekiel 11:19; cf. Ezekiel 36:26)? How are those who remain in sin-with only an extrinsic imputation of Christ's righteousness-'partakers of the divine nature' (2 Peter 1:4)? Medina concluded this series of questions by asking 'Did [God] not elect us in [Christ] before the foundation of the world that we should be holy and immaculate in his sight?' (Ephesians 1:4). Protestants would respond to a number of these objections and questions by pointing to the teaching on sanctification and regeneration, which does not appear to have featured prominently in Medina's discussion of Protestant soteriology. Nonetheless, even if the progress in Christian holiness were acknowledged more extensively, Protestant theologians made it very clear that even the most advanced Christian renewal could not withstand divine scrutiny. The question of the 'tribunal' often featured in Protestant polemics. Would a Roman Catholic put forward her infused righteousness at the judgment? Medina thought that the most important answer to many of the Lutheran arguments was a clear affirmation that 'we will not bring forward in our defense (in patrocinium) before the tribunal of Christ anything except the righteousness of 
Christ by whose merit and title we are sons of God and heirs of eternal life' (1580: 633). But the phrase of Christ referred to the efficient cause 'from whom all our justice is derived'; of Christ did not refer to the subject of the righteousness in Protestant sense whereby a Christian is righteous by the righteousness which remains in Christ. The righteousness of Christ which justifies is 'applied through faith, hope, and charity and by means [of these virtues] we are renewed in the spirit of our minds and are made holy and just before God' (1580: 634).

Medina brought this account of the sufficiency of infused or imparted righteousness into the context of the Christian's experience of imperfection. While he rejected the Protestant account of imputation, he arguably did not have the presumption in his own standing before God about which Luther worried. Though Medina affirmed that the Christian at baptism is made immaculate before God and that everything which is sin, strictly speaking, is taken away, the Christian life is nonetheless filled with impurities and imperfections. When the new creature, born again through the grace of the Holy Spirit, considers these imperfections and impurities, the Christian might think that there is more darkness than light (1580: 633). But Medina replied that the 'justice of faith and charity is 'of great worth (in magno pretio) before God'. The justified human being is like a seed compared to a mature tree, a candle to the light of the sun, a new child (proles) to a 'man of perfect age' (1580: 634). And God loves this seed, this flicker of light, this new child. Scripture teaches in 1 John 3:9, 'The one who is born of God does not sin because the seed of God remains in him'. Is it not enough (ne parum) to be born of God and to have the seed of God? Medina then asked, 'Has not the Savior said, "I ask you, Father, that they all might be one, as we are one?" Is it not enough that we are one with God?' (1580: 634; cf. John 17:11). And Medina then said, once again, 'the justice by which we are just is of great worth before God'. For Medina, it was of course no small thing to be a member of Christ's body and to have the Holy Spirit. Thus, for these Thomists, union with Christ makes it so that we are not as much shielded as healed and elevated to a divine life of membership in Christ's mystical body. The justice that is an effect of that union is of great value, even though Christians do not yet act or love as they will in heaven.

Though the Protestant formulation of the non-imputation of sin was seen as among the 'chief' Protestant errors and the source or root of other soteriological errors, addressing the imputation of Christ's righteousness caused some difficulties for Catholic theologians before and during the Council. Besides being skeptical of how imputation related to the Protestant account of original sin, the novelty of these discussions posed certain challenges. Soto said that, during the discussions at the Council of Trent, he expressed his suspicion of the idea of the imputed righteousness of Christ-and continued 
to be suspicious because of the hidden 'dangers' that Protestants 'concealed' in this terminology (178v) - but then said that others 'more expert than I' dealt with the matter 'in a more diligent disputation' (177r). Another major theologian at Trent, the Franciscan Andreas de Vega, stated quite explicitly that the details about the imputation of Christ's merits were rarely treated in the past and that the time before and during the Council allowed Catholic theologians to examine these matters with greater care (accuratissime) (1572: 667). And he dedicated an entire book to true and false ways of thinking about the imputation of Christ's righteousness. Although Catholic discussions of imputation have received little attention from scholars, rather elaborate debates about how one might properly understand the imputation of Christ's merits can be found in the works of post-Tridentine Catholic theologians (Vázquez 1605: 1274-86; Suárez 1858: 115-23; Torres 1623: 507-11; cf. McGrath 2005: 344-57; Lane 2006: 83-85). This theological development in Catholic theology arose largely in response to Protestant soteriology. It is important to note moments like the passages in Soto and Vega where major theologians at Trent recognized a development in soteriological discussion just before and during the Council. After the confessional documents of the Lutheran and Reformed churches and the Council of Trent's decrees and canons, early modern theologians continued to argue that the other side was slandering or at least misunderstanding their opponents. The shape of the debate and even the status quaestionis were not always as clear as these confessional statements might suggest.

Some Catholic theologians after Trent also engaged the refinements in the later tradition of Protestant theology, sometimes referred to as Protestant scholasticism or Protestant orthodoxy. Indeed, scholars such as Richard A. Muller have, over the past few decades, uncovered the rich refinements and elaborations of Protestant soteriology (e.g., Muller 2012; Muller 2017: 181324; Vainio 2008; for several essays on this topic, cf. Lehner, Muller, Roeber 2016, and Ballor, Gaetano, Sytsma 2019a). But Catholic engagement with Protestant scholasticism has received little scholarly attention. Although some Catholic theologians in the late sixteenth and seventeenth centuries mainly referred back to the sharpest claims of Martin Luther, John Calvin, and other early Reformers in their treatment of Protestant soteriology (e.g., Álvarez 1610: 29-32, 166-67), others made use of these later elaborations. Because Protestant scholastics replied directly to objections posed in Catholic theological works, especially the Controversies of the Jesuit Robert Bellarmine, it was often much easier to discern the state of the question in these works than in the theological polemics of the early sixteenth century.

An excellent illustration of a Roman Catholic elaboration of a Catholic teaching on Christ's imputed righteousness as well as an engagement with Protestant scholasticism is the two-volume Treatises on the Controversies of Faith 
by Adrian van Walenburch (d. 1669) and Peter van Walenburch (d. 1675). The Walenburch brothers, who were born in Rotterdam and who both served auxiliary bishops of Cologne at one point in their lives, were quite erudite and took what might be called an irenic approach to Protestant theology (Müller et al. 1981: 512). During Peter's time at Mainz in the 1650s, where a number of 'irenicists and reunionists worked on reunion projects and promoted the reduction of denominational differences' after the Peace of Westphalia (Müller et al. 1981: 511), he even offered Gottfried Wilhelm Leibniz help in his theological studies during the German philosopher's efforts to unify Christians (Antognazza 2009: 87, 121; Leibniz 1850: xlii, xlvii-xlviii, 180, 199). The Walenburchs, however, were not really early ecumenists; their ultimate goal appears to have been to prove that Magisterial Protestants could not justify their 'schism' from the Roman Catholic Church (Walenburch 1670: 5, 7, 42, 51, 610; cf. Parker 2008: 88, 133-34, 188). According to the Walenburchs, Protestant objections to Catholic teaching fell flat and certainly did not require the 'schismatic' posture of the previous 150 years or so. But this argumentative strategy led the Walenburchs to affirm that Protestants and Catholics agreed about points that certainly would not have appeared obvious to theologians during the first half of the sixteenth century, nor to many modern scholars. While I cannot say that the views of the Walenburchs were representative, the work of these two Catholic bishops appears to have been generally well-received by Catholic theologians throughout the eighteenth century (Serry 1709: 450-51; Tournely 1741: 592; Pozzo 1758: 64-65; Gazzaniga 1831: 64, 208, 236-37). The Walenburchs thought that there was now basic agreement on a number of points that may have surprised their predecessors. Extensive discussions of justification by faith alone (1670: 465-8), the confidence in one's salvation (1670: 496-503), and even good works and merit (1670: 541-610) yielded some statements of (supposed) consensus on quite a few issues that produced great controversy a century earlier. The Walenburchs' treatment of forensic justification and imputation, however, is most relevant to the issue of the remnants of $\sin$ in the baptized, which remained controversial. The Walenburchs acknowledged that, while the word justification in Scripture does sometimes mean the gift or reception of 'inherent justice' from God and the increase of this inherent justice, it could also refer to someone being pronounced or declared just in a forensic mode' (1670: 45, 48). One could think of justification as having a 'judicial' meaning inasmuch as one is approved 'in the judgment of God' (369). And this is not merely a claim that God's declaration, because of the power of God's word, is tantamount to making believers righteous. For the Walenburchs, justification understood in this forensic way does not immediately imply anything except the action and 'declaration' of God alone who justifies (1670: 48, 403). These Catholic bishops, therefore, did not reject a 
forensic account of justification, though they deemed such an account incomplete.

An account of justification without inherent justice or righteousness is incomplete, and the Walenburchs argued that 'Protestants in this time' acknowledged the presence of inherent justice (1670: 48, 369). The final quotation in this section-after citations of the Second Helvetic Confession, Peter Martyr Vermigli, Girolamo Zanchi, André Rivet, the Reformed Synopsis of a Purer Theology, and others-was from the major Lutheran theologian, Johann Gerhard (Leinsle 2010: 302-306; Preus 1970: 107-33), who wrote that there was no real controversy about whether 'the interior renewal and the good works which flow from it can be called justice, which we freely concede' (1670: 372). Protestant theologians, therefore, did not reserve the language of justice to their strict understanding of forensic justification or imputed righteousness; they were willing to use the term justice with reference to interior renewal or sanctification (1670: 432).

The Walenburchs certainly recognized that the Protestants distinguished justification from sanctification and that they associated justification with the 'forensic sense' (1670: 373). Catholics, on the other hand, used justification both in a forensic sense and as referring to the grant (collatio) of inherent justice. And the Walenburchs did not fail to point out that Catholics used the term in this broader way 'with Sacred Scripture'. The Protestant position thus remained problematic, but the acknowledgment of inherent justice was a crucial element for the Walenburchs. Protestants 'of our time' not only embraced this teaching of inherent righteousness but a strong account of the believer's incorporation into Christ's mystical body; the English Reformed theologian William Ames and others affirmed Bellarmine's discussion of salvation in terms of the union of Christ the head and his members in one body (1670: 374-75). The bond established between the believer and Christ by the Holy Spirit-according to which Christ's righteousness and satisfaction is 'our own'-shows that justification in later Protestantism was not a 'legal fiction' (fictio iuris) but a mysterious reality $(1670: 375,48)$.

The recognition of a forensic justification that did not rule out inherent, imparted righteousness is an important context for the Walenburchs' engagement with the Protestant teaching on imputation. They endorsed the following statement of Bellarmine: 'If the [Protestants] only want the merits of Christ to be imputed to us because they are bestowed (donata) to us and we can offer them to God the Father for our sins because Christ took on himself the burden of satisfying for us and for reconciling us to God the Father, this view of theirs would be correct' (1670: 373; cf. Bellarmine 1873b: 227). For Bellarmine, this was not the way in which Scripture and the Fathers spoke, and this would still not constitute the 'formal cause' of justification, but this way of formulating the imputation of Christ's righteousness was acceptable. 
The Walenburchs stated that later Protestants such as the Lutheran Johann Gerhard and the Reformed theologian William Ames saw this description of imputation as handing over the controversy to the Protestants. Indeed, the Walenburchs quoted the German Reformed theologian and irenic writer, Ludwig Crocius, who said that he would simply employ the 'Bellarminian definition' of imputation and said that he did not desire a better one. In his Bellarminus enervatus, William Ames wrote, 'We read everywhere in Paul that we become just (nos fieri) and are justified through Christ, through the death, blood, redemption, obedience, and righteousness of Christ and that this righteousness is imputed to us by God apart from works. This is the entirety of what we profess in this matter' (1670: 373; cf. Ames 1629: 136). The Walenburchs said that Ames 'spoke well' on this point because human beings are justified through the death, blood, redemption, obedience, and righteousness of Christ 'as through a meritorious cause'. They quoted Bellarmine as saying, 'it would not be absurd if someone said that the righteousness and merits of Christ are imputed to us since they are bestowed and applied to us as if we ourselves made satisfaction to God, as long as it is not denied that there is in addition an inherent righteousness, which is a true and absolute justice, to which glory not punishment is owed in the just judgment of God'. Although Ames and Gerhard saw these words of Bellarmine as confirming the Protestant view, the Wallenburchs argued that they should not be surprised by this passage because it was simply 'what Catholics teach' in conformity with Scripture (1670: 373-74).

The issue was whether this external, imputed righteousness alone justifies. According to the Walenburchs, Paul 'never calls the faithful just except from the inherent justice effected through the Spirit of Christ' (1670: 373). Christ is the one who satisfies for us to God the Father; Christ's righteousness is our satisfaction and our righteousness. The inherent righteousness does not satisfy God for 'our sins (culpa) or for the eternal penalty'. The inherent righteousness is an 'effect' of the satisfaction of Christ. But it is a part of the Catholic - and, for the Walenburchs, the biblical-account of justification. Imparted, inherent righteousness is the formal cause of justification inasmuch as this infused righteousness is the form in the soul by which the believer is rightly called just.

The Walenburchs thought, if Gerhard and Ames really thought that Bellarmine 'surrendered' the entire dispute to Protestantism, they should 'add nothing' to his articulation of the imputation of Christ's righteousness (1670: 374). The problem was that, for the Walenburchs, Protestants did add to this 'Bellarminian' idea of imputation their view about the contamination of the justified by $\sin$. Although they noticed some progress in the teaching on original sin as such, the old controversy still lingered. Some Protestant theologians now acknowledged that the formal element of original sin was removed 
at justification, which for the Walenburchs came close to saying that it was no longer sin, strictly speaking (1670:39-40). Nonetheless, Protestants did not fully embrace Bellarmine's statement that Christ's righteousness 'is imputed to us as far as the satisfaction which he accomplishes for us' but that, if the stains (maculae) and filth of sins inhere in us', we cannot be deemed just. Ames replied, 'if the justice of Christ is imputed to us, then we are certainly reckoned just in him' (1670: 374). The Walenburchs conceded that, in a restricted sense, 'we can be reckoned just in [Christ] insofar as the justice of Christ's satisfaction is ours'. But they embraced Bellarmine's view that 'we cannot be deemed pure and immaculate if the stains and filth of sins inhere in us' and said that 'Scripture nowhere pronounces the faithful just from the sole justice of Christ's satisfaction bestowed and imputed to them'. Rather, Scripture 'everywhere declares just and reckons just only those who, having been made participants of the merit and satisfaction of Christ, are cleansed through the grace and spirit of Christ and those in whom true justice inheres'. The Walenburchs thought that Ames was right to say that the 'debt of punishment' is satisfied, remitted, and not imputed because of the satisfaction of Christ imputed to us-the 'debtor is liberated from this obligation before his creditor'. As the Walenburchs put it, 'in forensic justification, the sinner in the judgment of God is a debtor of an eternal penalty. Christ Jesus the Mediator intervenes as one rich in merits and satisfies to God for their eternal penalty which man the sinner owes. When this satisfaction is imputed to the sinner, his eternal punishment is remitted, and he is liberated from his obligation (nexus) before the judge who is at the same time his creditor'.

The question that remained is whether the stains of sin are truly removed in justification and whether anyone could be called just, strictly speaking ( $a b$ solute), in whom the stain of sin inheres. Despite the fact that the Walenburchs did not think that the strict Protestant distinction between justification and sanctification was grounded in the language of Scripture, they thought that Ames addressed the substance of the matter when he wrote that "man is cleansed from guilt through justification and from inherent stain (macula) and depravity through sanctification' (1670: 374; cf. 1670: 402, 465). For the Walenburchs, Ames's affirmation that sanctification cleanses the stain of sin advanced the discussion considerably.

The Walenburch engaged some of the deepest Protestant concerns about confusing inherent righteousness with justification (according to the Protestant sense of the term). The Walenburchs made it quite clear that the inherent justice is not a cause but an effect of being accepted by God into a state of grace and friendship with God. As they put it, 'Catholics teach that God remits sins for the sinner from mere grace. God loves the sinner, in whom there is nothing lovable, not in himself but in his Son and on account of his Son, the guarantor (sponsor) of that sinner and his mediator' (1670: 
376). But they quoted a number of Protestant theologians who stated that the main issue was whether the inherent justice, even if imparted by God, could withstand divine scrutiny at the tribunal or divine judgment (1670: 371). The Walenburchs argued that Catholics agreed with Protestants that one should depend on Christ's righteousness at the tribunal. The Christian has confidence in the God who justifies sinners, bestows Christ's justice and merit to them, gratuitously infuses inherent justice, and lavishes eternal life on those who do what is good according to 'his liberal and gratuitous promise' (1670: 49). Confidence or trust (fiducia) is ultimately placed 'most securely' in God's kindness and mercy alone, which is why the 'Catholic Church has always observed' that those near to death be admonished not to trust in their own justice and, 'with an image of the crucifix before their eyes', to put 'every hope and confidence (fiducia) in the one righteousness of Christ (in una Christi justitia)' (1670: 50, 495). Nonetheless, though God could judge a man as just 'because he has the justice of Christ imputed to him', God does judge believers as really and 'perfectly' just because of their inherent justice (1670: 411). For the Walenburchs, this formal element in the believer is a crucial part of the Catholic account, but it does not eliminate the trust in Christ's merit and righteousness.

The Walenburchs of course acknowledged that the righteousness that inheres in Christians is 'inchoate' with respect to the righteousness which the saints possess in heaven. The heavenly righteousness is much 'more perfect' and 'protects the saints from every sin which the righteousness in us cannot accomplish', which is why the saints pray in this life, 'forgive us our debts' (1670: 385). The Walenburchs also said that Protestants and Catholics agreed that inherent righteousness is imperfect with respect to the righteousness of Christ imputed to us. Indeed, the righteousness of Christ imputed to believers 'infinitely exceeds our righteousness'. Although they know the point is controversial among Catholic theologians, they pointed out that some Catholics taught that inherent righteousness requires the 'liberal acceptation of God' to justify and purge from sins; the inherent righteousness is not so perfect that it could do so by its own nature. While the infused quality inherent in us is truly and really justice and sanctity, nonetheless 'by its own nature it does not purge us from sins except with the addition of a new will and favor of God forgiving sin'.

The Walenburchs clarified the question of the proper judgment of inherent justice at the end of one's life by rooting the discussion in divine promises. They stated that Catholics and Protestants agreed that eternal life and glory are not owed to the inherent righteousness from sheer justice. There is no necessity imposed on God of 'conferring glory to the one who has inherent righteousness' (1670: 386). Inherent righteousness is thus not by its nature the cause 'on account of which the faithful are accepted to life and eternal 
glory'. Rather, eternal life and glory are granted 'by grace and by the liberality of God'; God could, without injustice, not bestow eternal life on one with inherent righteousness, if one abstracts from the 'acceptation of God and the promise made manifest in the Word of God'. But in the context of these divine promises, which is the reality which Christians actually inhabit, there is a 'glorious' acceptance of inherent justice 'on account of the merits of Christ' according to which inherent righteousness is the 'formal cause by which man is constituted a child (filius) of God through the Holy Spirit dwelling in him and an heir of the kingdom that is gratuitously given on account of Christ and obtained through good merits'. The Walenburchs quoted Gerhard who saw this position about the need for this sort of divine acceptance of the 'supernatural form in the human soul' as a concession to the Protestant position. In this account, the cause of justification and salvation are only divine favor, even if God ordains that, when he justifies and saves, he also conjoins the renewal and regeneration which involves forms infused in the human soul. The Walenburchs argued that Gerhard confused the efficient cause of justification with the formal cause. 'No one doubts', they said, 'that the favor of God is the single (solitaria) efficient cause of justification'. A merciful acceptance is required; some theologians even required a 'new imputation of Christ's merits' for the conferral of eternal life. Nonetheless, the inherent righteousness 'accepted on account of Christ' is the proper, formal, and adequate cause according to which 'we are and we are called formally and intrinsically just', just as this inherent righteousness is the proper, formal, and adequate cause according to which 'we are and we are called heirs of eternal life'.

Although the Walenburchs freely granted that inherent righteousness of the justified is obviously not as perfect as the righteousness of the saints, let alone Christ, and that its acceptance for eternal life is ultimately rooted in divine promises, they refused any suggestion that this inherent righteousness is contaminated by sin. Bellarmine accused Protestants of saying that the inherent righteousness of the justified is more vice than virtue and more unrighteousness than righteousness. The Walenburchs said that Bellarmine was right to say so, though they recognized some clarifications from Protestants. A major concern was that the infused habit in itself is not contaminated by sin. Such a claim would be 'blasphemy' $(1670: 387,412)$ and made God the 'author of sin' (1670: 386). If God begins a good work, this work could not be evil and must be a 'good work', simply speaking. It cannot have any injustice mixed in, even though it can 'be perfected from day to day'. The Walenburchs insisted that that even the inchoate renewal is 'perfect justice' in the sense of being completely and essentially just. This is similar to how a boy is a 'perfect human being' as far as the essentials of being human, even though the boy will undergo 'perfecting' as far as growth and development (1670: 
387). The Walenburchs clarified the point when they described 'perfect justice' as that in which there 'is no injustice'. Although Protestants admitted inherent justice, Gerhard and other Protestant theologians nonetheless said that habitual inherent justice is 'imperfect and contaminated with much filth of sin (multis peccatorum sordibus)'. In reply to this position, the Walenburchs proclaimed, 'We do not see how a habit infused by God alone is said to be contaminated by sin without blasphemy'. The case of the baptized infant is especially clear in this context. All of the child's righteousness has God as its author. The 'node of the matter' is whether Protestants still insisted that the faithful one 'considered in himself' is damnable on account of the 'imperfection of inherent justice'. The habit infused in the child is not as perfect as the righteousness of Christ or even the saints, but the Walenburchs, like Catholic theologians before them, could not tolerate the idea that this habit is contamination by sin. The Walenburchs referred to the notion of a justice from God that is still 'damnable when considered in itself' as one of the 'paradoxes of your school'. Despite frequent recognition of agreement on soteriological issues, the Walenburchs said that these paradoxes 'will never make their way into the Church of Christ (pervenient ad Ecclesiam Christi)' (1670: 412).

The Walenburchs distinguished the question of the contamination of the infused habit from the sinfulness of the good works of Christians. It was one thing to say that the inherent justice imparted from God is contaminated and quite another to say that the contamination comes from 'the root of concupiscence', whose rebellion ultimately came from the sin of Adam (1670: 387; cf. 1670: 48). Despite this distinction, the Walenburchs saw it as a gratuitous, hyperbolic, and very harsh assertion to say that 'each and every work of the justified which proceeds from inherent justice also proceeds from the vicious beginning or from the remnants of sin' (1670: 387). Gerhard apparently thought that Bellarmine was unfair when the Jesuit theologian said the Lutheran position entailed that 'there is no true, actual justice in us'. Gerhard pointed out that Lutherans 'did not deny that there is the justice of true obedience'; they only denied that the inherent justice is 'perfect' and that it 'can stand before the judgment of God'. But the Walenburchs asked, 'how is it true justice when it is contaminated by sins?' The question of sin in the justified remained a central point of controversy.

The Walenburchs argued that not every good work of the justified springs from concupiscence. They disagreed with the Protestant view, expressed in confessional documents such as the Augsburg Confession, the Second Helvetic Confession, the Anglican Thirty-Nine Articles, and the Scots Confession, that the 'weakness in the flesh' and even the 'uncleanness of nature' of Christians make it impossible to fulfill God's law (1670: 544). Gerhard argued that 'absolute perfection requires ... love from the whole heart, mind, soul, and strength' and a continuous and uninterrupted fulfillment of the law. 
Gerhard was also quoted as specifically rooting the inability to achieve this sort of perfection in the 'remnants of original sin' along with the 'imperfection of our renewal' and 'the perpetual struggle of the flesh and spirit' (1670: 545) - the key issues for Protestant theologians in the first half of the sixteenth century as well. In reply, the Walenburchs agreed that the law is not fulfilled so perfectly that the justified 'do not mix together any venial sins with their good works throughout their whole life'. Protestants saw this concession as inconsistent with the perfect observation of the divine law. For many Protestants, all sins are by their nature mortal sins. The Catholic acknowledgement that venial sins are frequently committed should lead them to the Protestant view of the continual sinfulness of the Christian life. And even the recognition of the frequency of venial sins did not go far enough because Protestants held that each and every work of a justified person is 'stained by sins' and therefore not in perfect conformity with the law of God.

On the issue of venial sins, the Walenburchs seem to have been willing to concede quite a few of the Protestant concerns. They asserted that Catholics and Protestants agreed that not all sins are equal. When Protestants said that all sins are mortal in the reprobate, the Walenburchs interpreted this to mean that all the sins with which the reprobate die are punished eternally, whether those sins are more or less grave. The Walenburchs agreed. The pardon of venial sin was thus related to being in a state of grace and friendship with God. More importantly, the Walenburchs argued that no sin is by its nature venial in the sense that its pardon (venia) and remission could be obtained 'by the powers of nature alone without the mercy of God who forgives (sine misericordia Dei condonantis)' (1670: 39). The venial character of venial sins is partly rooted in the fact that they are less grave, but 'there is no sin that is so light (levis) that it can be washed away by the powers of nature'. Thus, if these venial sins were committed by someone who is not 'a just man provided with the grace of God and charity', those sins would be punished perpetually. These sins are only venial because they do not destroy charity, and this is true because God, because of his mercy, does not will that these acts destroy charity.

The Walenburchs were much more hostile to the position of Protestants that even the good works of Christians were contaminated by sin. For their discussion of the fulfillment of the law and good works, they quoted at great length from a few chapters of a work on justification by an irenic Scottish theologian and the first Protestant bishop of Edinburgh, William Forbes (1658: 139-68). The capacity to fulfill the law of God is not through the powers of free choice-an 'impious' view that was 'condemned many centuries ago' as the Pelagian heresy (1670: 545). Even through grace, the perfect fulfillment of the law-considered in its greatest rigidity as forbidding even the 
slightest turning aside from perfect charity towards God and neighbor- cannot be fulfilled for one's whole life or even for a long time. The experience of the faithful of falling into daily faults, which was so often pointed to by Protestant theologians, confirmed the daily need for remission of sins. And this was why, as Trent also said, the faithful not only humbly but truthfully pray the following words of the Lord's Prayer: 'forgive us our debts' (1670: 545; Denzinger 2012: no. 1537).

The Walenburchs thought that the divine law, which could at times be fulfilled by those in a state of grace, should not be considered rigidly but according to 'our little measure'. They endorsed Forbes's argument that God's requirements of the faithful must be understood in terms of the 'evangelical covenant' (foedus evangelicus). Living in accordance with this covenant leads human beings to become 'partakers of eternal life' (1670: 545; cf. 1670: 576). The standard of the 'evangelical covenant' or 'covenant of grace' can be fulfilled. Yet the Walenburchs and Forbes stated quite clearly that this standard is based upon God's 'paternal goodness and indulgence', which is always prepared to forgive all the faults of our infirmity and even the 'grave crimes', as long as 'serious repentance' and the 'zeal of avoiding' such acts occurs. God 'does not want to deal with us' in such a way that would reflect a desire to damn believers for falling into the 'smallest fault' or for not loving God 'with the supreme degree of perfection'. This 'covenant of grace' is set forth by God's mercy 'on account of Christ, and even this covenant can only be fulfilled by the justified with God's grace (1670: 547).

The framework of the evangelical covenant of divine mercy, however, did not conclude the controversy. According to the Walenburchs, Catholics and Protestants agreed that many works of the just, even those that are otherwise good, are stained by imperfections and venial sins. They even said that, when Protestants taught that 'all the works of the just are stained by sin', a Catholic could concede the claim if the all is understood collectively rather than distributively (1670: 548). In other words, since so many of the works of the just are stained by sin, such a claim is accurate when describing the whole collection of the works of a particular justified person. Yet considered distributively, that is, with each and every act considered separately, there is 'no foundation' for saying that all the works of the just are stained by sin. Thus, the question is whether any of these works can be unstained. Many Protestants answered negatively, while Catholics answered affirmatively. The Walenburchs argued that no one had proved that the 'vicious motion of concupiscence' concurred with each and every work of the just (1670: 548, 50). The justified frequently resist the motion of concupiscence, and it is wrong to say that one who resists sin with all her might is nonetheless sinning.

A similar line of reasoning applied to the issue of the command to love God with all one's heart. How could it be a sin if one loves God with all of 
one's powers? The fact that the saints in heaven love God more has much to do with the increase in their powers. The Walenburchs asked if those who posited the inability to love God to a sufficient degree to avoid sin considered the martyrs: 'Is the martyr who, for the testimony of Jesus Christ, submitted his neck to the ax sinning in that act ... and not loving God from his whole heart' (1670: 548, 50). But even when one is not performing the final act of a martyr or resisting the slightest motion of concupiscence with all one's powers, the acts of Christians could still be seen as immune from the stain and guilt of sin. They quoted Forbes who said that God 'graciously acquiesces' to what is possible according to the measure of faith and charity which is 'prescribed by the covenant of grace' (1670: 550). The law should not be considered according to its most rigorous standard or the supreme degree of perfection but 'according to the mind of the God who commands'. The Walenburchs acknowledged that Christians generally love less than they ought but that God as merciful towards the human race 'now deals sweetly and kindly on account of Christ'. The debt of love is fulfilled 'through the communion of the Spirit of Christ in those things which lead to his likeness' (1670: 562).

The Walenburchs thus clarified that, though Catholics must defend the notion that some of the works of the justified are uncontaminated by sin, none of the justified should boast too much about any good work. While boasting in works is wrongheaded and dangerous in part because all of these works depend on divine mercy, the other extreme that must be avoided isand they again quoted from Forbes (1658: 168) — to be ungrateful and unjust towards 'the grace of Christ' by denying that, through its powers, anything can be accomplished by the Christian which is not polluted by sin (Walenburch 1670: 551). Indeed, the Walenburchs acknowledged that good works done in a state of grace could be meritorious of glory.

The account of merit received an entire treatise and thus cannot be treated in detail here, but a number of their points clarify the issues discussed above. The merits of the faithful are born from the merits of Christ. The incorporation of members in the body or of branches in the vine are essential for the vitality of those members and branches; likewise, 'the faithful cannot do any good works meritorious of eternal life and worthy of the crown of justice except because they are in communion with Christ from whom they receive every power (virtus) of doing well' (1670: 559). Just as Protestants held good works to the strict and rigorous standard of the divine law, they made the standard of merit much more rigid than Catholic theologians (1670: 582; cf. Berti 1805: 264-68). The Walenburchs said that the crown is given 'according to the condition of struggle to which the faithful are called' (1670: 561 ). And merit is ultimately rooted in love. The compliance and service of a child are more valuable than that of a mercenary because the service of a child 'proceeds from the motive of love' (1670: 563). A human being loving 
God 'according to the law', the Walenburchs argued, 'merits as a mercenary' and obeys largely out of self-love (and they also noted that the obedience according to the law cannot even be accomplished by the powers of human nature alone after sin). By contrast, the faithful person loving God 'according to the Gospel' renounces self-love so that he or she might 'love God above all things' (1670: 564). And 'true justice and sanctity are fulfilled' in this love. Those who 'fulfill the law according to the Spirit of life which is in Christ Jesus' perform a service more pleasing to God and consequently is worthy of a greater reward before God, that is, 'happiness, life, and eternal glory'. And merit, properly speaking, is simply the acquisition of 'a right or title to a reward' (1670: 560). The Walenburchs addressed several of the scholastic controversies, though they did not want to impose the opinions of different scholastics on their Protestant interlocutors (e.g., 1670: 596). Eventually, they defined a meritorious deed in a theological context as a 'free action that proceeds from grace' done by a viator (or someone on the way to heaven) who is 'constituted in grace' (1670: 574). The precise relationship of these deeds to heavenly rewards was a matter of scholastic controversy among Catholics. The Walenburchs argued that Protestants 'of this time' accepted the parts of this definition, even though many of them still objected to this way of using the term merit.

The Walenburchs admitted that someone might ask why the Council of Trent defined this subject-matter about the meritoriousness of good works if it is largely a debate about the term itself and if Protestants acknowledged its key elements. The Walenburchs pointed out that things had changed since the 'beginning of the schism' (1670: 605). At that time, some Protestants denied free choice altogether, which would eliminate any possibility of merit. The Walenburchs acknowledged that early Protestants found, in the works of some medieval theologians, stronger accounts of works as having intrinsic worth and a kind of equality with the heavenly reward, but the problem was that they attributed these views to 'the whole Church'. But one of the key points was that early Protestants denied true merit because they taught that 'all the works of the just are stained by sin' (1670: 605; cf. 1670: 594-95). If early Protestants saw 'concupiscence remaining in those born again' as being sin, strictly speaking, then they understandably inferred that all good works proceeding from a justified person are rendered sinful by that concupiscence. And it is 'absurd' to think that sinful works, even if partly good through the progress of sanctification, would be meritorious before God. The Council of Trent thus set forth a definition about the meritoriousness of the good works of the justified as part of an argument that free choice is not extinguished, that concupiscence in those born again is not sin, strictly speaking, and that all the works of the just are not stained by sin. According to the Walenburchs, Trent did not support the particular theories of scholastic doctors but defined 
'what the whole Church held' about the good works of the just being meritorious.

The approach of the Walenburchs to the questions surrounding justification are worthy of greater study (and perhaps theological critique). Their view that Protestant scholasticism led to refinements and clarifications that brought about closer approximation between the major confessions of Western Christianity - on some, not all, issues - is supported by the work of some recent scholars (Sinnema 1985: 448-50; Muller 2017: 193; Ballor, Gaetano, Sytsma 2019b). Instead of viewing Protestant orthodoxy entirely in terms of a hardening of boundaries and as part of the process of confessionalization, the academic character of this enterprise made it possible to bring certain nuances to longstanding debates and, at the very least, grasp the status quaestionis more readily (cf. Raitt 2011: 131; Leinsle 2010: 298-302; see Muller 2012: 69, for a clear challenge to notion of later Reformed theologians' 'rigid orthodoxy'). More importantly, the Walenburchs' vivewpoint-whether wholly representative or not-indicates that clarifications of Catholic soteriology were possible after Trent and the Controversies of Robert Bellarmine. The Colloquy of Regensburg (1541) was not the last time before twentiethcentury ecumenical dialogues that Protestants and Catholics could affirm that there were agreements on doctrines contested by the early Reformers. Trent and the Protestant confessions were not the last word, even if the Council of Trent was deemed infallible and worthy of defense by the Walenburchs (1670: 134-35, 605).

Despite the Walenburchs' irenic approach and decades of debate between Catholics and Protestants, the issue of the sinfulness of Christians remained a central issue, just as it was in the earliest condemnations of Martin Luther. They acknowledged the sinfulness of many acts of Christians, the fact that venial sins are pardoned by the mercy of God on account of Christ, the seriousness of crying out daily for God to 'forgive us our debts', and the need for good works to be judged according to 'our little measure' and in terms of the 'evangelical covenant'. The inherent righteousness of the justified is an effect of the righteousness of Christ imputed to them. This inherent justice, let alone any act of free choice unaided by grace, does not merit justification nor does it satisfy for sins before God. The inherent righteousness of the justified on earth is inferior to that of the saints in heaven and infinitely inferior to Christ's righteousness.

Nonetheless, the Walenburchs saw it as blasphemy to say that inherent righteousness is imperfect in the sense of being sinful or contaminated by the stain of sin. Like Domingo de Soto and Bartolomé de Medina, the Walenburch brothers insisted on this point not primarily to defend the dignity of the good works of Christians but to give thanks to God for his grace that made sinners into children of God who are rightly and truly called just. One 
does not honor the sun by deeming the sky dark, nor does one praise the vine by considering the branches barren, nor does one esteem the body by calling its members ugly. Protestants saw Catholic teachings on infused righteousness, the meritoriousness of good works, purgatory, and quite a few others as detracting from the sufficiency of Christ's work on the Cross. From the earliest days of the Reformation, Catholic theologians deemed the Protestant view of sin in the justified as undermining the work of Christ as the Lamb of God who takes away the sins of the world.

\section{Bibliography}

Álvarez D (1610) De auxiliis divinae gratiae et humani arbitrii viribus, et libertate ac legitimata eius efficacia eorundem auxiliorum concordia. Rome: Stephanus Paulinus.

Ames W (1629) Bellarminus enervatus sive disputationes antibellarminianae, volume 4. Oxford: Guilelmus Turner.

Anderson HG, Murphy TA, and Burgess JA (eds) (1985) Justification by Faith: Lutherans and Catholics in Dialogue VII. Minneapolis: Augsburg Publishing House.

Antognazza MR (2009) Leibniz: An Intellectual Biogaphy. New York: Cambridge University Press.

Augustine (1998) Marriage and Desire. In Teske RJ (trans) Answer to the Pelagians, II: Marriage and Desire, Answer to the Two Letters of the Pelagians, Answer to Julian. Hyde Park, NY: New City Press.

Backus I and Goudriaan A (2014) 'Semipelagianism': The Origins of the Term and its Passage into the History of Heresy. The Journal of Ecclesiastical History 65: 25-46.

Ballor JJ, Gaetano MT, and Sytsma DS (eds) (2019a) Beyond Dordt and De Auxiliis: The Dynamics of Protestant and Catholic Soteriology in the Sixteenth and Seventeenth Centuries. Leiden: Brill.

Ballor JJ, Gaetano MT, and Sytsma DS (2019b) Introduction: Augustinian Soteriology in the Context of the Congregatio De Auxiliis and the Synod of Dordt. In Ballor JJ, Gaetano MT, and Sytsma DS (eds) Beyond Dordt and De Auxiliis: The Dynamics of Protestant and Catholic Soteriology in the Sixteenth and Seventeenth Centuries. Leiden: Brill, pp. 1-18.

Batka L (2014) Luther's Teaching on Sin and Evil. In Kolb R, Dingel I, and Batka L (eds) The Oxford Handbook of Martin Luther's Theology. New York: Oxford University Press, pp. 233-53.

Bellarmine R (1870) Nona controversia generalis de baptismo et confirmatione. In Fèvre J (ed) Roberti Bellarmini opera omnia, volume 3. Paris: L. Vivès. 
Bellarmine R (1873a) Decima quarta controversia generalis de amissione gratiae et statu peccati. In Fèvre J (ed)Roberti Bellarmini opera omnia, volume 5. Paris: L. Vivès.

Bellarmine R (1873b) Decima quinta controversia generalis de reparatione gratiae. In Fèvre J (ed) Roberti Bellarmini opera omnia, volume 6. Paris: L. Vivès.

Berti G (1805) De theologicis disciplinis, volume 2. Madrid: Apud Filiam D. Joachimi Ibarra.

Billings T (2007) Calvin, Participation, and the Gift: The Activity of Believers in Union with Christ. New York: Oxford University Press.

Bryas C (1674) Thomistarum triumphus in perpetuum firmatus, id est, Sanctorum Augustini et Thomae, gemini ecclesiae solis, inconcussa concordia. Douai: Antonius Dieulot.

Calvin J (1547) Acta Synodi Tridentinae cum Antidoto per Joann. Calvinum. [Geneva: Jean Gérard].

Calvin J (1975) Antidote to the Council of Trent-1547. In Dillenberger J (ed) John Calvin: Selections from His Writings. Missoula, MT: Scholars Press for The American Academy of Religion

Castaldo C (2019) Justification and Conversion: Attractions and Repulsions to Rome. In Barrett M (ed) The Doctrine on Which the Church Stands or Falls: Justification in Biblical, Theological, Historical, and Pastoral Perspective. Wheaton: Crossway, pp. 812-38.

Chemnitz M (1578) Examen Concilii Tridentini. Frankfurt am Main.

Chemnitz M (1615) Loci theologici, volume 1. Wittenberg: Wolfgang Meissner. Chemnitz M (1971) Examination of the Council of Trent: Part 1, translated by Kramer F. St. Louis: Concordia Publishing House.

Clark RS (2006) Iustitia Imputata Christi: Alien or Proper to Luther's Doctrine of Justification? Concordia Theological Quarterly 70: 269-310.

De Franceschi SH (2018) Thomisme et théologie moderne: L'École de saint Thomas à l'épreuve de la querelle de la grâce $\left(X V I I^{e}-X V I I I^{e}\right)$. Paris: Artège Lethielleux.

Denzinger H (2012) Enchiridion symbolorum definitionum et declarationum de rebus fidei et morum, 43rd edition, edited by Hünermann P, Fastiggi R, and Nash AE. San Francisco: Ignatius Press.

Forbes W (1658) Considerationes modestae et pacificae controversiarum, de iustificatione, de purgatorio, de invocatione sanctorum et Christo Mediatore, eucharistia. London: Thomas Roycroft.

Gazzaniga PM (1831) De gratia Dei actuali, et habituali. In Praelectiones theologiae habitae in Vindobonensi Universitate, volume 6. Bassano: Remondini.

Gonet JB (1875) Clypeus theologiae thomisticae contra novos eius impugnatores, volume 1. Paris: L. Vivès.

Hampson D (2001) Christian Contradictions: The Structures of Lutheran and Catholic Thought. New York: Cambridge University Press. 
Helm P (2010) Calvin at the Cenre. New York: Oxford University Press.

Hoskins S and Fleischacker D (eds) (2017) Justified in Jesus Christ: Evangelicals and Catholics in Dialogue. Bismarck, ND: University of Mary Press.

Joint Declaration on the Doctrine of Justification by the Lutheran World Federation and the Roman Catholic Church (2000). Grand Rapids: Eerdmans.

Kolakowski L (1995) God Owes Us Nothing: A Brief Remark on Pascal's Religion and on the Spirit of Jansenism. Chicago: The University of Chicago Press.

Kolb R and Trueman CR (2017) Between Wittenberg and Geneva: Lutheran and Reformed Theology in Conversation. Grand Rapids: Baker.

Lane ANS (2006) Justification by Faith in Catholic-Protestant Dialogue: An Evangelical Assessment. New York: T\&T Clark.

Lehner UL, Muller RA, and Roeber AG (eds) The Oxford Handbook of Early Modern Theology, 1600-1800. New York: Oxford University Press.

Leibniz GW (1850) A System of Theology, translated by Russell CW. London: Burns and Lambert.

Leinsle UG (2010) Introduction to Scholastic Theology, translated by Miller MJ. Washington, D.C.: The Catholic University of America Press.

Lemos T (1702) Acta omnia congregationum ac disputationum quae coram SS. Clemente VIII et Paulo V summis pontificibus sunt celebratae in causa et controversia illa magna de auxiliis divinae gratiae. Louvain: Aegidius Denique.

Luther M (1957) The Leipzig Debate. In Grimm HJ (ed) Career of the Reformer $I$, volume 31 of Luther's Works. Philadelphia: Muhlenberg Press.

Luther M (1958) Defense and Explanation of All the Articles, 1521. In Forell GW (ed) The Career of the Reformer II, volume 32 of Luther's Works. Philadelphia: Muhlenberg Press.

Luther M (1961) Lectures on Romans, edited by Pauck W. Louisville: The Westminster Press.

Maas K (2019) The First and Chief Article: Luther's Discovery of Sola Fide and Its Controversial Reception in Lutheranism. In Barrett M (ed) The Doctrine on Which the Church Stands or Falls: Justification in Biblical, Theological, Historical, and Pastoral Perspective. Wheaton: Crossway, pp. 657-92.

MacCulloch D (2003) The Reformation. New York: Viking.

MacDonald G (2018) Martin Chemnitz' Examen Decretorum Concilii Tridentini (1566-1573): A Cornerstone in the Construction of Confessional Europe. In François W and Soen V (eds) Between Trent, Rome and Wittenberg, volume 1 of The Council of Trent: Reformation and Controversy in Europe and Beyond. Göttingen: Vandenhoeck \& Ruprecht, pp. 325-38.

Malloy CJ (2005) Engrafted into Christ: A Critique of the Joint Declaration. New York: Peter Lang.

Marshall B (2012) Beatus vir: Aquinas, Romans 4, and the Role of 'Reckoning' in Justification. In Levering $\mathrm{M}$ and Dauphinais $\mathrm{M}$ (eds) Reading Romans with St. Thomas Aquinas. Washington, DC: The Catholic University of America Press, pp. 216-37. 
Matava RJ (2016) Divine Causality and Human Free Choice: Domingo Báñez, Physical Premotion and the Controversy de Auxiliis Revisited. Leiden: Brill.

McGrath A (2005) Iustitia Dei: A History of the Christian Doctrine of Justification, 3rd edition. New York: Cambridge University Press.

Muller RA (2012) Calvin and the Reformed Tradition: On the Work of Christ and the Order of Salvation. Grand Rapids: Baker Academic.

Muller RA (2017) Divine Will and Human Choice: Freedom, Contingency, and Necessity in Early Modern Reformed Thought. Grand Rapids: Baker Academic.

Müller W, et al. (1981) The Church in the Age of Absolutism and Enlightenment, volume 6 of History of the Church, edited by Jedin H and Dolan J, translated by Holst GJ. New York: Crossroad.

Medina B (1580) Expositio in Primam secundae angelici doctoris D. Thomae Aquinatis. Venice: Petrus Dehuchinus.

Nacchiante G (n.d.) Enarrationes piae, doctae, et catholicae, in Epistolam D. Pauli ad Romanos. Venice: Josephus Vicentinus.

O'Gara M (2006) The Significance of the Joint Declaration on the Doctrine of Justification and the Next Steps in Ecumenical dialogue. In Stumme WC (ed) The Gospel of Justification in Christ: Where Does the Church Stand Today? Grand Rapids: Eerdmans, pp. 27-41.

Parker CH (2008) Faith on the Margins: Catholics and Catholicism in the Dutch Golden Age. Cambridge, MA: Harvard University Press.

Pelikan J (1984) Reformation of Church and Dogma (1300-1700), volume 4 of The Christian Tradition: A History of the Development of Doctrine. Chicago: The University of Chicago Press.

Pereira B (1603) Secundus tomus selectarum disputationum in Sacram Scripturam, continens octo disputationes super Epistola Beati Pauli ad Romanos. Ingolstadt: Adam Sartorius.

Pereira JL (2013) Augustine of Hippo and Martin Luther on Original Sin and Justification of the Sinner. Göttingen: Vandenhoeck \& Ruprecht.

Pozzo F (1758) Ragionamento sopra gli studi ecclesiastici. Rome: Giuseppe e Niccolò Grossi.

Preus RD (1970) The Theology of Post-Reformation Lutheranism: A Study of Theological Prolegomena. Saint Louis: Concordia Publishing House.

Raith C (2014) Aquinas E Calvin on Romans: God's Justification and Our Participation. New York: Oxford University Press.

Raitt J (2011) European Reformations of Christian Spirituality (1450-1700). In Holder A (ed) The Blackwell Companion to Christian Spirituality. Malden, MA: Wiley-Blackwell, pp. 122-38.

Root M (2006) Continuing the Conversation: Deeper Agreement on Justification as Criterion and on the Christian assimul iustus et peccator. In Stumme WC (ed) The Gospel of Justification in Christ: Where Does the Church Stand Today? Grand Rapids: Eerdmans, pp. 42-61. 
Rorem P (2001) Augustine, the Medieval Theologians, and the Reformation. In Evans GR (ed) The Medieval Theologians: An Introduction to Theology in the Medieval Period. Malden, MA: Blackwell, pp. 365-72.

Serry JH (1709) Historia congregationum de auxiliis divinae gratiae sub summis pontificibus Clemente VIII et Paulo V. Antwerp: Societas.

Sinnema D (1985) The Issue of Reprobation at the Synod of Dort (1618-19) in Light of the History of This Doctrine. PhD thesis, University of St. Michael's College, Toronto.

Soto D (1549) De natura et gratia. Paris: Ioannes Foucher.

Soto D (1551) In Epistolam Divi Pauli ad Romanos ... [et] De natura et gratia. Salamanca: Andreas de Portonariis.

Stamps RC (2019) Faith Works: Properly Understanding the Relationship between Justification and Sanctification. In Barrett M (ed) The Doctrine on Which the Church Stands or Falls: Justification in Biblical, Theological, Historical, and Pastoral Perspective. Wheaton: Crossway, pp. 505-32.

Suárez F (1858) De merito, quod est effectus gratiae sanctificantis. In Berton C, R. P. Suarez ... opera omnia, volume 12. Paris: L. Vivès.

Torres L (1623) Tractatus de gratia. Lyon: Ludovicus Prost, haered. Roville.

Tournely H (1741) Praelectiones theologiae de Deo et divinis at[t]ributis quas in Scholis Sorbonicis habuit, volume 1. Paris: Apud Viduam Raymundi Mazieres, \& Joannem Bapt. Garnier, Reginae Typographos \& Bibliopolas.

Triglot Concordia: The Symbolical Books of the Evangelical Lutheran Church (1921). St. Louis: Concordia Publishing House.

Vainio O (2008) Justification and Participation in Christ: The Development of the Lutheran Doctrine of Justification from Luther to the Formula of Concord (1580). Leiden: Brill.

Vázquez G (1605) Commentarii, ac disputationes in Primam secundae S. Thomae, volume 2. Madrid: Iustus Sanchez Crespo.

Vega A (1572) De iustificatione doctrina universa. Cologne: Gervinus Calenius \& Haeredes Quentelii.

Walenburch A and Walenburch P (1670) Tractatus speciales, de controversiis fidei, volume 2. Cologne: Ioannes Wilhelmus Friess Iunior. 